\title{
Water Quality Monitoring and Cadmium Contamination in the Sediments of Mae Tao Stream, Mae Sot District, Tak Province, Thailand
}

\author{
P. Weeraprapan, C. Phalaraksh, S. Chantara, and M. Kawashima
}

\begin{abstract}
Some lands and streams at Mae Sot District, Tak Province, Thailand are polluted by cadmium $(\mathrm{Cd})$ which leach from the zinc mine. The objectives of present study were to evaluate physico-chemical parameters of Mae Tao Stream and Cd concentration in the sediments. The water and sediment samples were collected from the upstream and downstream of Mae Tao Stream from April 2011 to February 2012. The downstream sites are affected by the water from the zinc mine. Physico-chemical parameters such as Temperature, Water Velocity, pH, Electrical Conductivity, Total Dissolved Solid, Dissolved Oxygen, Nutrients (Nitrate, Ammonium and Orthophosphate), Suspended Solids, Alkalinity and Total Hardness were measured. Judged from the parameters, Mae Tao Stream was classified to Type III of the Surface Water Quality Standard of Thailand for agriculture at all sampling sites. Cd concentrations in the sediments were measured in the range of $0.84-7.86 \mathrm{mg} \mathrm{kg}^{-1}$. In the sediments of polluted sites, $\mathrm{Cd}$ concentrations exceeded the European maximum permissible level of $3.0 \mathrm{mg} \mathrm{kg}^{-1}$ for Agricultural Soil. It is important to continue to monitor the physico-chemical parameters and the cadmium concentrations in the sediments, and the bio-assessment should be begun around the stream.
\end{abstract}

Index Terms-Water quality, cadmium, sediment, monitoring, Mae Tao stream.

\section{INTRODUCTION}

The cadmium contamination was reported in rice, soil and sediment in around Mae Tao Stream, the main source of water supply for agriculture, which is located at Mae Sot District, Tak Province in the north of Thailand [1], [2]. Mae Tao Stream passes through a zinc rich area where the zinc mining has been actively operated for more than 30 years. Cadmium usually occurs in association with zinc ore and is a by-product of zinc mining. About $69.2 \%$ of the sediment samples of Mae Tao Stream exceeded the European maximum permissible level of $3.0 \mathrm{mg} \mathrm{kg}^{-1}$ [3]-[5].

Cadmium concentrations were low in the sediments before reaching the zinc area, became much higher when the stream

Manuscript received April 5, 2014; revised June 5, 2014.

P. Weeraprapan and M. Kawashima are with the Environmental Science Program, Faculty of Science, Chiang Mai University, Chiang Mai, 50200, Thailand (e-mail: p.weeraprapan0405@gmail.com, kawa@edu.shiga-u.ac.jp).

C. Phalaraksh is with the Department of Biology, Faculty of Science, Chiang Mai University, Chiang Mai 50200, Thailand (e-mail: chitcholp@gmail.com).

S. Chantara is with the Department of Chemistry, Faculty of Science, Chiang Mai University, Chiang Mai 50200, Thailand (e-mail somporn.chantara@gmail.com). passed through this area, and then decreased according to the distance from the zinc area. Cadmium is a heavy toxic metal which causes environmental problems. Cadmium is concentrated in a human body by the food chain and/or damages to the ecosystem [6]. Thanee et al. showed the heavy contamination of $\mathrm{Cd}$ in the sediments in Ban Pha De (Zinc area) [7].

Water quality monitoring of the stream has become important more and more to check the effects by careless disposal of mining activities. Through the monitoring of physico-chemical parameters and cadmium concentration, it is necessary to establish the level of contamination in the water. Sediment samples have also been widely used to monitor cadmium contamination.

The objective of this study were to evaluate of water quality and to assess impacts of zinc mine on physico-chemical properties and the present level of cadmium contamination in the sediments of Mae Tao steam.

The obtained data will be used as basic research information that can be used as a tool for environmental quality assessment.

\section{MATERIALS AND METHODS}

\section{A. Study Area}

Mae Tao stream is located between latitude $16^{\circ} 39^{\prime} 90^{\prime \prime}$ $-15^{\circ} 40^{\prime} 28^{\prime \prime} \mathrm{N}$ and longitude $098^{\circ} 36^{\prime} 66^{\prime \prime}-098^{\circ} 42^{\prime} 26^{\prime \prime}$ E Mae Sot district, Tak province in the north of Thailand, where is in the mountain area of the border between Thailand and Myanmar. Mae Tao Stream is vital for life in Mae Sot District and is the main freshwater resource for many villages, meeting nearly all the demands for drinking water, irrigation and agricultural. There is the zinc mine at the upstream of Mae Tao Stream in Phra That Padaeng Subdistrict. Operation of the zinc mining was started in 1982, and this area has been affected by the adverse impacts of heavy metals, especially cadmium. The sampling sites are shown in Fig. 1; Site MT1 (Ban Tumseua) and Site MT2 (Before enter to the Pa Daeng) are located upstream of zinc mine and does not accept the water from the mine, and Site MT3 (Ban Phade) and Site MT4 (Ban Maetao Mai) are located downstream of Zn mine and polluted sites.

\section{B. Sampling Collection}

Waters and sediments were collected at 4 sampling sites every 2 months from April 2011 to February 2012.

At each sampling site, some physico-chemical parameters were measured in the fields, and then the water samples and 
sediments were brought to laboratory for analysis.

Water samples were collected manually using polyethylene bottles. All bottles were cleaned with $2 \% \mathrm{HNO}_{3}$ and then rinsed with distilled water prior to use. All samples were taken approximately $30 \mathrm{~cm}$ beneath the water surface. Sediments were collected and kept in the sealed containers until the digestion process of the next day.

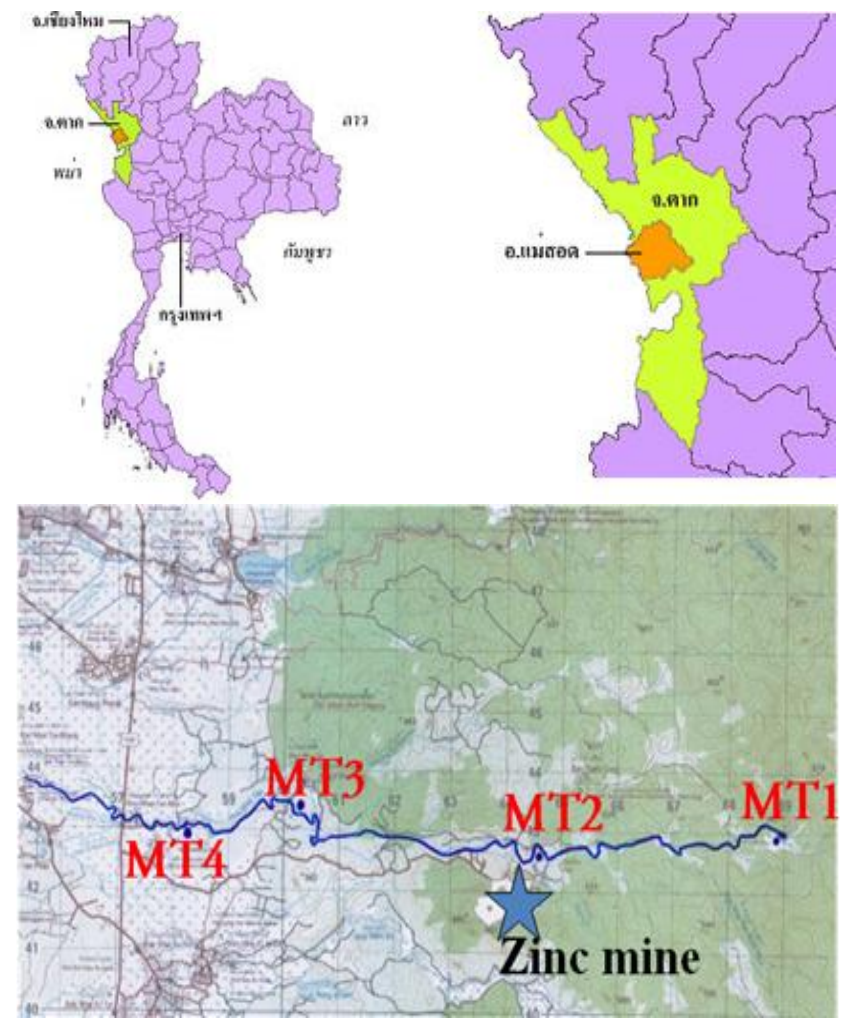

Fig. 1. Sampling sites in Mae Sot District, Tak Province, Thailand.

\section{Water Quality Measurement}

Physico-chemical parameters such as water temperature, water velocity, pH, Electrical Conductivity (EC), Total Dissolved Solid (TDS), Dissolved Oxygen (DO) were measured in the field. Suspended Solids (SS), Alkalinity, Total Hardness and Nutrients (Nitrate-N, Ammonia-N and Orthophosphate) were measured in the Freshwater Freshwater Freshwater Biomonitoring Research Laboratory, Faculty of Science, Chiang Mai University [8].

\section{Analysis of Cadmium in Sediments}

The sediment samples were dried at $140^{\circ} \mathrm{C}$ in hot air oven for 4 hours, and then $500 \mathrm{mg}$ of the sample was digested with $3 \mathrm{ml}$ of nitric acid $\left(\mathrm{HNO}_{3}\right)$ and $1 \mathrm{ml}$ of hydrochloric acid $(\mathrm{HCl})$. These mixtures were evaporated on a hot plate. Digested samples were allowed to cool to approximately $37^{\circ} \mathrm{C}$, followed by further addition of $4 \mathrm{ml}$ of concentrated $\mathrm{HNO}_{3}(2 \%)$. Flasks were returned to hot plates and digested again until approximately $3 \mathrm{ml}$ volume remained. Finally, the digested samples were diluted to $25 \mathrm{ml}$ with deionized water, transferred to separate glass bottles and kept prior to analyses. Finally, cadmium concentration was measured using atomic absorption spectrophotometer (AAS).

\section{E. Statistical Analysis}

Average (X) and standard deviation (SD) of items at each study sites were calculated. The results of experiments were evaluated by statistical difference due to extended exposure periods between the 6 months. Effects of seasonal changes of water quality and concentration of cadmium were evaluated with a one way analysis of variance (ANOVA), processed by the SPSS 17.0 computer package. Results of testing were considered significant if calculated P-values were $<0.05$.

\section{RESULTS AND DISCUSSION}

\section{A. Physico-Chemical Parameters}

The physico-chemical parameters were considered as the important principles in the identification of the quality and type of the water. Means, standard deviations and ranges of measured parameters at four sampling sites are shown in Table I. The $\mathrm{pH}$ measurement is one of the most important and frequently used tests in water chemistry [9].

Natural freshwaters usually have a $\mathrm{pH}$ range between 6 and 8 . The $\mathrm{pH}$ of the water is important because it affects the solubility and availability of nutrients which can be utilized by aquatic organisms. According to the present results, $\mathrm{pH}$ values ranges from 7.70 (Site MT2) to 8.51 (Site MT3) and present normal level of natural water. Statistical results showed significant difference $(p<0.05)$ among the sites, but $\mathrm{pH}$ values are within the permissible limit $(5.00-9.00)$ of Surface Water Quality Standards of Thailand (1995). Electrical conductivity (EC) is the ability of the water to conduct an electrical current, and is an indirect measure of the ion concentration [9]. The major ions that contribute to the measurement of conductivity are sodium, potassium, calcium, magnesium, chloride, sulfate ions. Other ions that contribute to conductivity to a smaller degree are carbonate, bicarbonate, nitrate and phosphate [10]. In this study, EC values ranged from 365 to $402 \mu \mathrm{S} \mathrm{cm}^{-1}$ (Table I) and at all the sampling sites EC were very high. The result tested statistically showed no significant difference among sampling sites. TDS values were measured in the range of 193 to $212 \mathrm{mg} \mathrm{L}^{-1}$. TDS values were not significant different among sampling sites. The high value of TDS usually is caused by leaching of ions to the stream from soil. The concentration and composition of TDS in natural waters is determined by the geology of the drainage, atmospheric precipitation and the water balance (evaporationprecipitation) [11]. For freshwater animals, TDS toxicity is a result of osmotic stress and its impacts on the osmoregulatory capability of the organism [12]. The concentrations of dissolved oxygen (DO) were 7.24 to $7.67 \mathrm{mg} \mathrm{L}^{-1}$. The statistical results of DO showed no significant difference among sampling sites. DO were more than $4 \mathrm{mg} \mathrm{L}^{-1}$ of the Surface Water Quality Standard at all sampling sites in both upper and lower areas of the mine.

The nutrients such as nitrate- $\mathrm{N}\left(\mathrm{NO}_{3}-\mathrm{N}\right)$, ammonia- $\mathrm{N}$ $\left(\mathrm{NH}_{3}-\mathrm{N}\right)$ and orthophosphate $\left(\mathrm{O}-\mathrm{PO}_{4}\right)$ were measured. $\mathrm{NO}_{3}-\mathrm{N}$ and $\mathrm{NH}_{3}-\mathrm{N}$ are the most common forms of nitrogen in aquatic systems, and is often the limiting factor for biological productivity of the water.

The highest value of $\mathrm{NO}_{3}-\mathrm{N}$ was detected at Site MT3. This site is near the agriculture area and the soil with fertilizer seems to be eroded into the water. As the result, the concentration of $\mathrm{NO}_{3}-\mathrm{N}$ increased in the stream. The lowest 
value of $\mathrm{NO}_{3}{ }^{-} \mathrm{N}$ was detected at Site MT1. Based on statistical analysis, there were significant difference $(p<0.05)$ among the sampling sites. $\mathrm{NH}_{3}-\mathrm{N}$ is excreted by animals and produced with decomposition of plants and animals, and may return to concentration of $\mathrm{NO}_{3}-\mathrm{N}$ increased in the stream. The lowest value of $\mathrm{NO}_{3}-\mathrm{N}$ was detected at Site MT1. Based on statistical analysis, there were significant difference $(p<0.05)$ among the aquatic system. It is also one of the most important pollutants. In Mae Tao Stream, concentrations of $\mathrm{NH}_{3}-\mathrm{N}$ were in the range of $0.01-0.53 \mathrm{mg} \mathrm{L}^{-1}$ as shown at Table I. There was no significant difference among sampling sites. At almost all the sampling sites, the concentration of $\mathrm{NH}_{3}-\mathrm{N}$ did not exceed the water quality standard of Thailand $\left(0.5 \mathrm{mg} \mathrm{L}^{-1}\right)$. $\mathrm{O}-\mathrm{PO}_{4}$ is generally considered to be the primary nutrient limiting algal and plant growth in fresh waters. In this study, the ranges of $\mathrm{O}-\mathrm{PO}_{4}$ concentration were $0.24-0.43 \mathrm{mg} \mathrm{L}^{-1}$ as shown in Table I. O- $\mathrm{PO}_{4}$ concentration levels were not significant different among the sites. Alkalinity and total hardness of Mae Tao Stream were almost same values among 4 sampling sites as shown in Table I. According to the physico-chemical parameters, the water qualities did not exceed the values of the Surface Water Quality Standard of Thailand and seems to have no effect from the zinc mine.

TABLE I: MEANS, StANDARd DEVIATIONS AND RANGES (IN BRACKET) OF PHYSICO-ChEMICAL PARAMETERS IN MAE TAO STREAM

\begin{tabular}{|c|c|c|c|c|}
\hline Site name & Ban Tumseua & Before enter to the Pa Daeng & Ban Phade & Ban Maetao Mai \\
\hline Site code & MT 1 & MT 2 & MT 3 & MT 4 \\
\hline Latitude and Longitude & N 16³9' 994"E 098²4' 265" & $\begin{array}{l}\mathrm{N} 16^{\circ} 39^{\prime} 904^{\prime \prime} \\
\text { E } 098^{\circ} 40^{\prime} 263^{\prime \prime}\end{array}$ & $\begin{array}{l}\text { N } 16^{\circ} 40^{\prime} 282^{\prime \prime} \\
\text { E } 098^{\circ} 37^{\prime} 710^{\prime \prime}\end{array}$ & $\begin{array}{l}\mathrm{N} 16^{\circ} 40^{\prime} 126^{\prime \prime} \\
\text { E } 098^{\circ} 36^{\prime} 667^{\prime \prime}\end{array}$ \\
\hline Elevation (m) & 523 & 417 & 270 & 258 \\
\hline $\begin{array}{l}\text { Water Temperature } \\
\left({ }^{\circ} \mathrm{C}\right)\end{array}$ & 22.8 & 24.5 & 24.4 & 23.9 \\
\hline $\begin{array}{l}\text { Water velocity } \\
\qquad\left(\mathrm{m} \mathrm{s}^{-1}\right)\end{array}$ & $\begin{array}{l}0.37 \pm 0.26 \\
(0.07-0.90)\end{array}$ & $\begin{array}{l}0.43 \pm 0.44 \\
(0.08-1.43)\end{array}$ & $\begin{array}{l}0.44 \pm 0.08 \\
(0.33-0.61)\end{array}$ & $\begin{array}{l}0.34 \pm 0.20 \\
(0.14-0.76)\end{array}$ \\
\hline $\mathrm{pH}$ & $\begin{array}{c}8.08 \pm 0.19^{\mathrm{ab}} \\
(7.80-8.33)\end{array}$ & $\begin{array}{l}7.97 \pm 0.17^{\mathrm{a}} \\
(7.70-8.27)\end{array}$ & $\begin{array}{c}8.16 \pm 0.22^{b} \\
(7.80-8.51)\end{array}$ & $\begin{array}{c}8.07 \pm 0.21^{\mathrm{ab}} \\
(7.80-8.41)\end{array}$ \\
\hline $\begin{array}{l}\text { Electrical conductivity } \\
\qquad\left(\mu \mathrm{S} \mathrm{cm}^{-1}\right)\end{array}$ & $\begin{array}{l}365 \pm 58 \\
(230-403\end{array}$ & $\begin{array}{c}389 \pm 90 \\
(192-466)\end{array}$ & $\begin{array}{l}395 \pm 77 \\
(216-475)\end{array}$ & $\begin{array}{c}402 \pm 80 \\
(198-475)\end{array}$ \\
\hline $\begin{array}{l}\text { Total Dissolved Solid } \\
\qquad\left(\mathrm{mg} \mathrm{L}^{-1}\right)\end{array}$ & $\begin{array}{c}193 \pm 30 \\
(119-214)\end{array}$ & $\begin{array}{c}212 \pm 50 \\
(104-258)\end{array}$ & $\begin{array}{c}196 \pm 50 \\
(112-254)\end{array}$ & $\begin{array}{l}211 \pm 41 \\
(114-254)\end{array}$ \\
\hline $\begin{array}{l}\text { Dissolved oxygen } \\
\left(\mathrm{mg} \mathrm{L}^{-1}\right)\end{array}$ & $\begin{array}{l}7.27 \pm 0.37 \\
(6.80-7.80)\end{array}$ & $\begin{array}{l}7.26 \pm 0.21 \\
(7.00-7.60)\end{array}$ & $\begin{array}{l}7.67 \pm 0.28 \\
(7.20-8.20)\end{array}$ & $\begin{array}{l}7.24 \pm 0.31 \\
(6.80-7.80)\end{array}$ \\
\hline $\begin{array}{l}\text { Nitrate-nitrogen } \\
\left(\mathrm{mg} \mathrm{L}^{-1}\right)\end{array}$ & $\begin{array}{l}1.12 \pm 0.51^{\mathrm{a}} \\
(0.40-2.00)\end{array}$ & $\begin{array}{l}1.58 \pm 0.65^{\mathrm{ab}} \\
(0.40-2.80)\end{array}$ & $\begin{array}{l}1.95 \pm 0.89^{b} \\
(0.70-3.40)\end{array}$ & $\begin{array}{l}1.64 \pm 0.91^{\mathrm{b}} \\
(0.20-3.40)\end{array}$ \\
\hline $\begin{array}{l}\text { Ammonium-nitrogen } \\
\left(\mathrm{mg} \mathrm{L}^{-1}\right)\end{array}$ & $\begin{array}{l}0.13 \pm 0.11 \\
(0.01-0.37)\end{array}$ & $\begin{array}{l}0.17 \pm 0.06 \\
(0.10-0.36)\end{array}$ & $\begin{array}{l}0.19 \pm 0.10 \\
(0.05-0.40)\end{array}$ & $\begin{array}{l}0.22 \pm 0.15 \\
(0.01-0.53)\end{array}$ \\
\hline $\begin{array}{l}\text { Ortho-phosphate } \\
\qquad\left(\mathrm{mg} \mathrm{L}^{-1}\right)\end{array}$ & $\begin{array}{l}0.31 \pm 0.20 \\
(0.11-0.78)\end{array}$ & $\begin{array}{l}0.34 \pm 0.25 \\
(0.12-0.89)\end{array}$ & $\begin{array}{l}0.24 \pm 0.10 \\
(0.09-0.44)\end{array}$ & $\begin{array}{l}0.43 \pm 0.34 \\
(0.12-1.47)\end{array}$ \\
\hline $\begin{array}{l}\text { Suspended solids } \\
\qquad\left(\mathrm{mg} \mathrm{L}^{-1}\right)\end{array}$ & $\begin{array}{l}15.00 \pm 19.42^{\mathrm{a}} \\
(1.00-60.00)\end{array}$ & $\begin{array}{c}26.38 \pm 25.62^{\mathrm{ab}} \\
(2.00-75.00)\end{array}$ & $\begin{array}{l}61.05 \pm 67.24^{\mathrm{ab}} \\
(2.00-184.00)\end{array}$ & $\begin{array}{l}77.38 \pm 99.04^{\mathrm{b}} \\
(2.00-255.00)\end{array}$ \\
\hline Alkalinity $\left(\mathrm{mg} \mathrm{L}^{-1}\right)$ & $\begin{array}{l}230 \pm 5.3^{\mathrm{a}} \\
(226-240)\end{array}$ & $\begin{array}{l}220 \pm 6.9^{b} \\
(212-272)\end{array}$ & $\begin{array}{l}207 \pm 7.6^{b c} \\
(199-215)\end{array}$ & $\begin{array}{l}210 \pm 9.0^{c} \\
(202-220)\end{array}$ \\
\hline $\begin{array}{c}\text { Hardness } \\
\left(\mathrm{mg} \mathrm{L}^{-1} \text { as } \mathrm{CaCO}_{3}\right)\end{array}$ & $\begin{array}{l}270 \pm 38 \\
(210-300)\end{array}$ & $\begin{array}{c}270 \pm 46 \\
(180-300)\end{array}$ & $\begin{array}{c}240 \pm 68 \\
(150-300)\end{array}$ & $\begin{array}{l}265 \pm 40 \\
(210-300)\end{array}$ \\
\hline
\end{tabular}

a,b,c $=$ Significant difference $(p<0.05)$ among groups of sampling periods.

$P$ values are shown for only variables that showed significant differences between sites. Different superscript letters per variable across sites indicate significant differences established using the Tukey HSD test while the same superscript letter indicates no significant difference exist.

\section{B. Cadmium Concentrations in the Sediments}

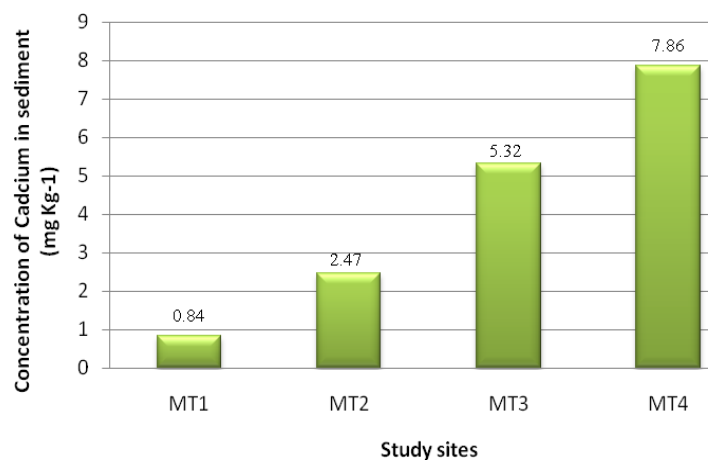

Fig. 2. Concentration of cadmium in sediments of Mae Tao stream.
Cadmium (Cd) concentrations in the sediments of Mae Tao Stream were analyzed. As shown in Fig. 2, the highest concentration of cadmium was detected at site MT4 (7.86 mg $\left.\mathrm{kg}^{-1}\right)$, while the lowest concentration was detected at site MT1 (0.84 $\left.\mathrm{mg} \mathrm{kg}^{-1}\right)$. Cd concentration at Sites MT3 and MT4 were much higher than those at Sites MT1 and MT2. Cd concentrations of Sites MT3 and MT4 exceeded the European Maximum Permissible Levels (>3.0 $\mathrm{mg} \mathrm{kg}^{-1}$ ).

MT1 and MT2 are located at the upstream of the zinc mine, and MT1 is very far from the zinc mine. Sites MT3 and MT4 are located at the downstream of the zinc mine. As Mae Tao Stream accepts the water from the zinc mine, it is clear that the source of $\mathrm{Cd}$ is the zinc mine. $\mathrm{Cd}$ contamination in sediment can affect the water quality and bioaccumulation of 
metals in aquatic organisms, resulting in potential long term implication on human health and ecosystem [13].

The behavior and distribution of cadmium in sediments may be affected by water hydrology and many biological, chemical and geological operations occur in aquatic system [14].

In addition, excretion and elimination of exoskeletons by abundantly occurring plankton and by settlement of particulate matter probably have played a significant role in enhancing the concentration of heavy metals in the sediments [15].

\section{CONCLUSION}

The water qualities in Mae Tao Stream, Tak Province was classified to Type III of the Surface Water Quality Standard of Thailand for agriculture at all sampling sites, as the physico-chemical parameters at all sampling sites did not exceed values of the Standard of Thailand. However, it was confirmed that Mae Tao Stream was still polluted by cadmium, which has been discharged from zinc mine. The concentrations of cadmium in the sediments were very high at the downstream of zinc mine compared with those at the upstream of zinc mine. Cd concentrations in the sediments were measured in the range of $0.84-7.86 \mathrm{mg} \mathrm{kg}^{-1}$. In the sediments of polluted sites, $\mathrm{Cd}$ concentrations exceeded the European maximum permissible level of $3.0 \mathrm{mg} \mathrm{kg}^{-1}$ for Agricultural Soil. It is important to continue to monitor the physico-chemical parameters and the cadmium concentrations in the sediments, and the bio-assessment should be begun around the stream.

\section{ACKNOWLEDGMENT}

The authors would like to thank Centre for Excellence on Environmental Health Toxicology (EHT) for sponsor and financial support. We also thank members of Freshwater Biomonitoring Research Laboratory and Environmental Chemistry Research Laboratory, Faculty of Science, Chiang Mai University for their assistance of samplings and water quality analyses. Chiang Mai University and Graduate school of Chiang Mai University are gratefully acknowledged.

\section{REFERENCES}

[1] R. W. Simmons, P. Pongsakul, D. Saiyasitpanich, and S. Klinphoklap, "Elevated levels of cadmium and zinc in paddy soils and elevated levels of cadmium in rice grain downstream of a zinc mineralized area in Thailand: Implications for public health," Environmental Geochemistry and Health, vol. 27, issue 5-6, pp. 501-511, 2005.

[2] A. Sriprachote, P. Kanyawongha, K. Ochiai, and T. Matoh, "Current situation of cadmium-polluted paddy soil, rice and soybean in the Mae Sot District, Tak Province, Thailand," Soil Science and Plant Nutrition, pp. 1-11, 2012

[3] Pollution Control Department, "Cadmium contamination in Mae Tao Creek, Mae Sot District, Tak Province,” Bangkok: Thailand Ministry of Natural Resources and Environment, 2004.

[4] Distribution of cadmium and absorption by rice plants in areas nearby the zinc mine in Mae Sot District, National Research for Environmental and Hazardous Waste Management Chulalongkorn University, Bangkok: Chulalongkorn University, 2005.

[5] R. W. Simmons, O. Sukreeyapongse, A. D. Noble, and N. Chinabut, "Report of LDD-IWMI land zoning and risk assessment activities undertaken in Phatat Pha Daeng and Mae Tao Mai Subdistricts, Mae Sot, Tak Province, Thailand," Bangkok: International Water Management Institute, 2005.
[6] S. Satarug, J. R. Baker, S. Urbenjapol, M. Haswell-Elkins, P. E. Reilly, D. J. Williams, and M. R. Moore, "A global perspective on cadmium pollution and toxicity in non-occupationally exposed population," Toxicology Letter, vol. 137, pp. 65-83, 2003.

[7] I. Thanee and C. Phalaraksh, "Diversity of aquatic insects and their functional feeding group from anthropogenically disturbed streams in Mae Sot District, Tak Province, Thailand," Chiang Mai Journal of Science, vol. 39, no. 3, pp. 399-409, 2012.

[8] APHA, AWWA and WPCF, Standard Methods for the Examination of Water and Wastewater, $18^{\text {th }}$ ed. American Public Health Association, Washington D.C., 1992.

[9] A. D. Apha and Eaton, Standard Methods for the Examination of Water and Wastewater, American Public Health Association, Mary Ann H. Franson, American Water Works Association Ed., 2005.

[10] G. Fernandez, G. M. Chescheir, R. W. Skaggs, and D. M. Amatya, "WATGIS: A GIS-based lumped parameter water quality model," Transactions of the ASAE, vol. 45, no. 3, pp. 593-600, 2002.

[11] P. K. Weber-Scannell and L. K. Duffy, "Effects of total dissolved solids on aquatic organisms: A review of literature and recommendation for salmonid species," American Journal of Environmental Sciences, vol. 3, no. 1, pp. 1-6, 2007.

[12] W. L. McCulloch, W. L. Goodfellow, and J. A. Black, "Characterization, identification and confirmation of total dissolved solids as effluent toxicants," Environmental Toxicology and Risk Assessment, vol. 2, pp. 213-227, 1993.

[13] C. Fernandes, A. Fontainhas-Fernandes, F. Peixoto, and M. A. Salgado, "Bioaccumulation of heavy metals in Liza saliens from the Esomriz-Paramos coastal lagoon, Portugal," Ecotoxicology and Environmental Safety, vol. 66, pp. 426-431, 2007.

[14] K. Mohiuddin, Y. Ogawa, H. M. Zakir, K. Otomo, and Shikazono, "Heavy metals contamination in water and sediments of an urban river in a developing courtly," International Journal of Environmental Science and Technology, vol. 8, no. 4, pp. 723-736, 2011.

[15] R. Sankar, L. Ramkumar, M. Rajkumar, J. Sun, and G. Ananthan, "Seasonal variations in Physico-chemical parameters and heavy metals in water and sediments of uppanar estuary, Nagapattinam , India," Journal of Environmental Biology, vol. 31, no. 5, pp. 681-686, 2010.

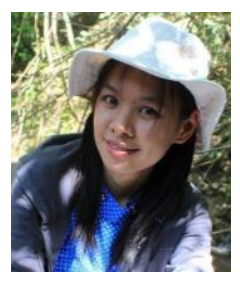

P. Weeraprapan was born in Chiang Mai, Thailand. on May 8, 1984. She got the Ph.D. degree in environmental science program from Faculty of Science, Chiang Mai University. She holds a bachelor of science degree in chemistry from Chiang Mai University, Chiang Mai, Thailand. And, a master degree in environmental science. Her master's thesis is Accumulation of cadmium and its effects on growth of some ornamental plants and weeds. Now, she is focus on cadmium in sediments and aquatic insects. Doctoral's Thesis: Effects of heavy metals on diversity, deformity and element concentration change of non-biting midge larvae (Diptera: Chironomidae) in Mae Tao Stream, Mae Sot District, Tak Province, Thailand. She is studying in the Environmental Science Program, Faculty of Science, Chiang Mai University, where she is the member of the Freshwater Bioindicator Research Laboratory. Scholarship for Centre for Environmental Health Toxicology (EHT)

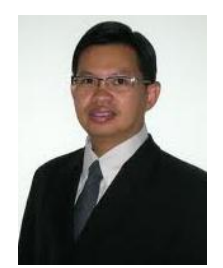

C. Phalaraksh was born in Thailand. He got the $\mathrm{Ph} . \mathrm{D}$. degree in environmental toxicology from Imperial College of Science, Technology and Medicine, University of London, UK. He is an assistant professor in the Department of Biology, Faculty of Science, Chiang Mai University, where he is the head of the Freshwater Bioindicator Research Laboratory. He has been invited by Japan International Cooperation Agency (JICA) as a lecturer for the JICA International Training Program in Aquatic Environment for over 5 years. He was also invited by Swedish International Development Cooperation Agency (SIDA) and Yunnan University as a lecturer for the Advance International Training Program. He organized numbers of international seminars and training program in the "Aquatic environmental education" collaborated with Shiga University and Ramsar Center Japan (RCJ) for many years. His research interests are primarily in the areas of Aquatic Insect Ecology, in particular both Taxonomy and Environmental Toxicology. In the past 10 years, his research had emphasized Bio-monitoring technique to investigate anthropogenic water pollution. 


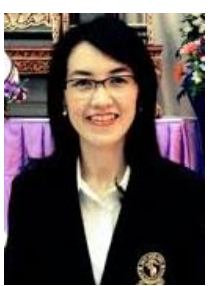

S. Chatara was born in Thailand. She got the Ph.D. degree at Saarland University, Saarbruecken, Germany and Dr. rer. nat. in biogeography from Trier University, Germany. She is an assistant professor in the Environmental Science Program, Faculty of Science, Chiang Mai University, where she is the head of the Environmental Science Program, Faculty of Science, Chiang Mai University. Her research interests are sampling and analysis of atmospheric acid deposition, analysis of polycyclic aromatic hydrocarbons (PAHs) in atmospheric particulate, development of passive samplers for determination of ambient $\mathrm{NO}_{2}$, chemical composition of atmospheric particulate matters i.e. $\mathrm{PM}_{25}$, $\mathrm{PM}_{10}$, biomass burning and its impacts on atmospheric environment and use of bioindicators for monitoring and assessment of air quality.

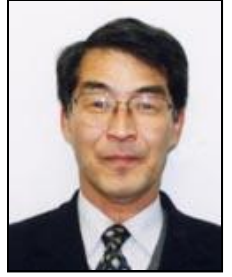

M. Kawashima was born at Japan. He got Ph.D. degree in 1977 in the area of analytical chemistry of Technetium. He is working as a visiting professor in Environmental Science Program, Faculty of Science, Chiang Mai University since 2011, after he retired from Shiga University, Japan. Presently, his specialty is in environmental science and education. $\mathrm{He}$ is having 110 of journal publications and 162 numbers of conference publications. 